$\gamma$

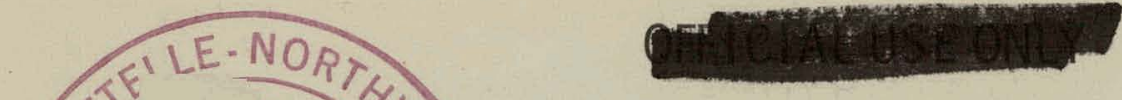

BNWL-B-333

Special

Distribution

\title{
RADIOLOGICAL IMPACT OF A NUCLEAR \\ CENTER ON THE ENVIRONMENT
}

J.K. Soldat

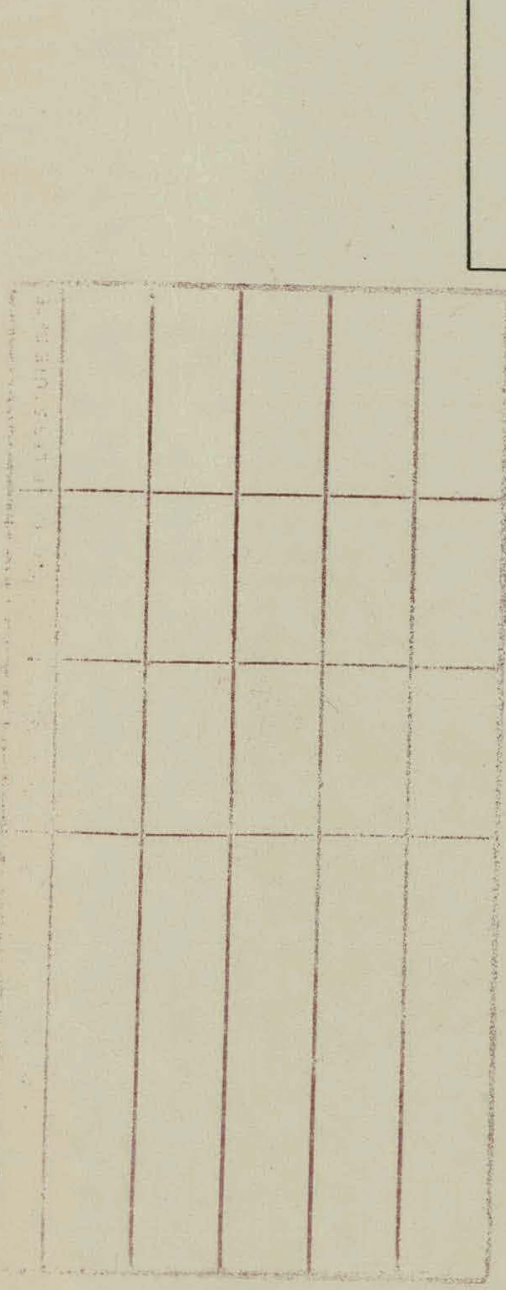

JANUARY 1974

This report is intended primarily for internal use by the sponsoring organization and Battelle.

Prepared for the U.S. Atomic Energy Commission under Contract AT(45-1):1830 


\section{DISCLAIMER}

This report was prepared as an account of work sponsored by an agency of the United States Government. Neither the United States Government nor any agency Thereof, nor any of their employees, makes any warranty, express or implied, or assumes any legal liability or responsibility for the accuracy, completeness, or usefulness of any information, apparatus, product, or process disclosed, or represents that its use would not infringe privately owned rights. Reference herein to any specific commercial product, process, or service by trade name, trademark, manufacturer, or otherwise does not necessarily constitute or imply its endorsement, recommendation, or favoring by the United States Government or any agency thereof. The views and opinions of authors expressed herein do not necessarily state or reflect those of the United States Government or any agency thereof. 


\section{DISCLAIMER}

Portions of this document may be illegible in electronic image products. Images are produced from the best available original document. 


\title{
PATENT STATUS
}

This doction confidence solely for use in performta

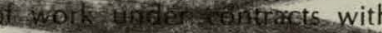
This document is not to be published nasitf contents otherwisentissebingterthor used for purposes other than specified above before patent approval for such release or use has been secured, upon request, from the Chief, Chicago Patent Grom W.5. Atomic Energy Commission, 9800 So. Cass Avenue, Argonne, Illinois, 60439.

\section{PRELIMINARY REPORT}

This report contains information of a preliminary nature prepared in the course of work under Atomic Energy Commission Contract AT(45-1)-1830. This information is subject to correction or modification upon the collection and evaluation of additional data.

\section{NOTICE}

The report was prepared as an account of work sponsored by the United States Government. Neither the United States nor the United States Atomic Energy Commission, nor any of their employees, nor any of their contractors, subcontractors, or their employees, makes any warranty, express or implied, or assumes any legal liability or responsibility for the accuracy, completeness or usefulness of any information, apparatus, product or process disclosed, or represents that its use would not infringe privately owned rights.

\author{
PACIFIC NORTHWEST LABORATORY \\ uperaled by \\ BATTELLE \\ for the \\ U.S. ATOMIC ENERGY COMMISSION \\ Under Contract AT(45-1)-1830
}


BNWL-B-333

RADIOLOGICAL-IMPACT OF A NUCLEAR

CENTER ON THE ENVIRONMENT

by

J. K. Soldat

January 1974

NOTICE

This report was prepared as an account of work sponsored by the United States Government. Neither the United States nor the United States Atomic Energy

Commission, nor any of their employees, nor any of their contractors, subcontractors, or their empinyrogs, aldkes ally wartanty, express or implied, or assumes any legal liability or responsibility for the accuracy, completeness or usefulness of any information, product or process disclosed, or represents that its use would not infringe privately owned rights.

\section{BATTELLE}

PACIFIC NORTHWEST LABORATORIES

RICHLAND, WASHINGTON 99352 


\section{CONTENTS}

RADIOLOGICAL IMPACT OF A NUCLEAR CENTER

ON THE ENVIRONMENT

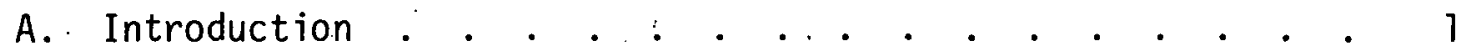

B. Control of Radioactive Effluents. : . . . . . . . . 1

C. Fuel Fabrication Facilities . . . . . . . . . . . 4

D. Nuclear Power Plants. • . . . . . . . . . . . . 6

E. Fuel Reprocessing Plants . . . . . . . . . . . . . y

F. Waste Management Facilities . . . . . . . . . . . 10

G. "Actinide Burner" Nuclear Reactor . . . . . . . . . 12

H. Overall Radiological Impact on Man . . . . . . . . . 12

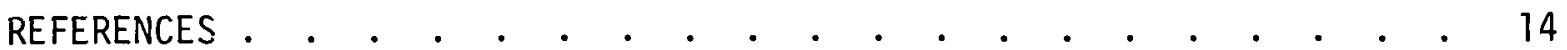


RADIOLOGICAL IMPACT OF A NUCLEAR CENTER ON THE ENVIRONMENT

J. K. Soldat

\section{A. INTRODUCTION}

This report discusses briefly the potential radiological impact of a conceptual Nuclear Energy Center (NEC) on the environment. Principal attention is directed to the estimated radiation doses received by man. Experience at operating nuclear facilities has shown that, barring unusual circumstances, regulation of radiation doses received by man to levels consistent with currently accepted guidelines will ensure that the doses to other biota are inconsequential.

The discussion addresses, in a generic sense, the routine release rates of radionuclides from fuel fabrication plants, nuclear reactors, reprocessing plants and interim waste storage facilities associated with such a NEC. The radiation doses resulting from such releases are summarized briefly, but details of the dose calculations are not presented. Further analysis of the potential radiological impact will have to be undertaken once a specific site is chosen. Depending upon the actual site characteristics, the radiological impact could be different than derived here for the generic site, but in all probability the net impact would not be significantly greater because of the conservative assumptions employed.

\section{B. CONTROL OF RADIOACTIVE EFFI.IIFNTS}

All industrial plants handling radionuclides have radioactive waste (radwaste) systems that treat the waste streams containing radionuclides. These systems are referred to as the 1 iquid, gas or solid radwaste systems in accordance with the physical form of the waste streams being treated. The purpose of the radwaste systems is to minimize release of radionuclides to the environment and the consequent radiation dose to the general public.

The radwaste systems can be designed for all degrees of treatment from essentially zero up to very sophisticated systems which result in virtually 
no release of radionuclides to the environment. The costs for operating these systems also have a broad range from a low value for minimal treatment up to high values for sophisticated treatment.

The AEC has a general. policy that the radiation dose received by the general public shall be "as low as practicable" which is defined as "as low as is practicably achievable taking into account the state of technology and the economics of improvement in relations to benefits to the public health and safety and in relation to the utilization of atomic energy in the public interest."(1) This has been translated into design guides, in proposed Appendix I to 10 CFR 50, which defines the Lerm "as low as practicable" in relation to radiation doses that the general public might receive as a result of radionuclide releases from nuclear power plants. Such design guides have not been proposed for reprocessing or fabrication plants, but probably will be issued based upon a control philosophy similar to that for Light Water Reactor (LWR) power plants.

The radiation dose received by the general public, as a result of radionuclide release from a plant, depends primarily on the design of the radwaste systems; the distance between the plant and the nearest members of the general public, and the pathways for radionuclide travel to the public. Of particular importance is the thyroid dose to infants consuming milk containing radioiodine from the air-grass-cow-milk pathway.

In general, the proposed 10 CFR 50 Apprndix I guidelines for radiation dose are easily achievable for external exposure to gaseous effluent at a 500-meter $(1640 \mathrm{ft})$ distance between the reactor plant and the site boundary to which the public has unlimited access. The limits are also achievable, but with somewhat more difficulty, for access to that boundary of foraging milk cows which provide milk to infants. As the distance between the plant and the nearest point of public access increases, the radiation dose to the public decreases. As an example, when the releases are from a 100-meter stack, increasing the site boundary distance from 
500 to 2000 meters decreases the dose from radioactive gas release to a person at the fenceline by a factor of about 5 to 10 because of greater dilution in the air.

The Appendix I guidelines of $5 \mathrm{mrem} / \mathrm{yr}$ for the most highly exposed individual of the public are easily achievable for LWR power stations of 1000-MWe capacity. In addition, AEC Document WASH-1258 describes liquid radwaste systems capable of reducing the maximum individual dose rate to as low as $0.1 \mathrm{mrem} / \mathrm{yr}$ from the liquid effluents released from a nominal 2400 MWe, two reactor power station regardless of whether they are Boiling Water Reactors (BWR) or Pressurized Water Reactors (PWR) or whether they are sited on a river, lake or ocean. On this basis it should be possible to place as much as 30,000 to 40,000 MWe total capacity at a nuclear center without exceeding the Appendix I guides for exposure to liquid effluents.

The previous discussion was 1 imited to LWR reactors. At the present time the "as low as practicable" guides for HTGR's, LMFBR's and fuels reprocessing and fabrication plants have not been set. The guides will probably be similar. For reprocessing plants this may be a very severe limitation since the very nature of the process is to release the fission products from the fuel. The reprocessing plant siting Document ORNL-4451, (2) states that LWR plants of capacity of greater than 6 to 10 tons/day will have to have more efficient iodine removal equipment than that demonstrated in present technology. If LMFBR fuels, cooled 30 days are to be processed the iodine removal efficiency must be improved four to six orders of magnitude over present technology.

Each of the several types of nuclear facilities expected to be located within a nuclear energy center (NEC) will routinely release radioactive gases, liquids, and/or solids to the environment under the "low as practicable" phllosophy. In a general way, the total impact of the facilities is the sum of the impacts caused by each facility. However, the individuals receiving the highest doses will not necessarily be identical for each geographically-separated facility and the doses to the maximum individual will not necessarily be completely additive, especially in the instance of gaseous effluents. 
Several mathematical models developed for calculating radiation doses to man and other biota from radioactive materials released to the environs have been reported in detail in the literature. Some of these models were specifically designed to treat accidental or acute releases $(3,4)$ al though they can be applied with modifications to chronic releases. ${ }^{(5,6)}$ other models were designed to calculate radiation doses in a large region of the United States from chronic releases. $(7,8)$ Applications of these models to the estimation of radiological impact of nuclear facilities for inclusion in the Environmental Reports required by the National Environmental Protection Agency (NEPA) have also been discussed in the literature. $(9,10)$

\section{FUEL FABRICATION FACILITIES}

In an NEC fuel fabrication facilities will be required for both uranium and plutonium LWR fuels as well as for LMFBR fuel. Fuels for any demonstration gas-cooled breeder reactor, which might be sited at the center, could either be fabricated and reprocessed onsite for each of siting or offsite for economic reasons.

In the uranium plant, uranium is received as either the hexifluoride or oxide powder. It is converted to the oxide, formed into pellets, sintered, etc., and then placed in zirconium tubes. The tubes are sealed and then assembled into finished assemblies. The plant ventilation system employs adequate safeguards to prevent the release of significant amounts of particulate matter.

The plutonium fabrication plant has several additional steps in the process. The plutonium may have to be converted to an oxide, blended with uranium oxide and then formed into pellets. The pellets, after further treatment, are then placed in tubcs and wclded closed. Up to this point a11 operations have taken place in gloveboxes because of the highly radiotoxic nature of plutonium. The remainder of the process parallels the uranium assembly line steps. The releases from the plutonium fabrication 
plant are held to insignificant levels by extensive air filtration equipment, so that both plants do not require significant controlled access or low population zones surrounding them.

The potential environmental impact of a mixed-oxide fuel fabrication plant was addressed in Document BNWL-1697. (11) Figures 5 to 8 . of that report illustrate the 50-year dose commitment to bone and lung of a Standard Man inhaling plutonium continuously released throughout a 50-year life of the facility. The doses were calculated for the maximum sector (highest air concentrations) versus distance from the facility and for two release heights, ground level and 100 meters, and the results were normalized to a chronic release rate of $1 \mu \mathrm{g} / \mathrm{yr}$ (i.e., 1 microgram/year). The highest dose commitments were associated with a ground-level release, which would be more typical for a fuel fabrication plant than a 100-meter release.

A typical release rate for the 1000 tonnes/yr fuel plant sited in the nuclear energy center would be about $50 \mu \mathrm{g} / \mathrm{yr}$. (12) Assuming a ground level release (Figures 5 and 7 of BNWL-1697) and using the curve for the new ICRP Task Group Lung Model, a release rate of $50 \mu \mathrm{g} / \mathrm{yr}$ would lead to $50-\mathrm{yr}$ dose commitments of $100 \mathrm{mrem}$ to the bone and $2 \mathrm{mrem}$ to the lung. The dose per year of operation was not calculated and would vary with time since startup, being higher in later years. "Average" doses per year of operation could be taken to be about $2 \mathrm{mrem}$ to bone and $0.05 \mathrm{mrem}$ to lung at a distance of 1000 meters.

At a distance of 2,000 meters, the 50-year dose commitments and "average" doses per year would be reduced to about one-fourth of those above.

The radiological impact of a LMFBR fuel fabrication plant should be similar to that discussed above for the mixed-oxide plant. The radiological impact of a uranium fuel plant, however, would be very much less, so much less that the impact of chemical rather than radioactive releases to the environment would be of more concern. 


\section{NUCLEAR POWER PLANTS}

Each nuclear reactor has a core region containing the fuel elements. In addition, a supply of fresh fuel elements is stored onsite just prior to the annual refueling outage, and spent fuel elements may be stored for about 6 months after removal from the reactor before they are shipped to a reprocessing $p l a n t$.

Operation of the reactor creates radioisotopes in the reactor structural materials, the coolant and in the fuel element cladding and end supports. Most of these radioisotopes are immobile because they are part of the permanent equipment, but small amounts are created in or enter the coolant and travel throughout the coolant and the associated purification

and waste systems. Small amounts also escape into other parts of the reactor building and eventually are transported to the radiation waste systems for appropriate treatment, storage and release to the environment.

The primary radioisotopes of interest are those in the fuel elements. The immobile ones in the structural materials normally present an insignificant hazard. A general estimate of the total quantity of radioisotopes in the fuel elements for typical power reactors is given in Table 1.

Estimated release rates of radionuclides with liquid and gaseous effluents from the current and near-future generation of nuclear power reactors can be found in Environmental Impact Statements prepared by the AEC in response to applications for operating licenses and construction permits. Current AEC practice is to normalize the liquid release rates estimated by an applicant to a total of $5 \mathrm{Ci} / \mathrm{yr}$, exclusive of tritium. Tritium release rates are estimated to be $20 \mathrm{Ci} / \mathrm{yr}$ for a BWR and $350 \mathrm{Ci} / \mathrm{yr}$ for a PWR. Guidance on the specific radionuclide content of liquid wastes versus radwaste system complexity can be found in WASH-1258. (1)

Radiation doses to individuals living at a 500-meter site boundary distance can easily be maintained below the Appendix I guideline of $5 \mathrm{mrem} / \mathrm{yr}$ without the need for excessive radwaste treatment. The same radwaste systems which meet this guideline result in total-body, population doses of less than 50 person-rem/yr for a 2400 MWe PWR station situated on 
TABLE 1. Typical Radioisotopes in Power Reactor Fue ${ }^{(a)}$

\begin{tabular}{|c|c|c|c|}
\hline & Location & Material & $\mathrm{Ci}$ \\
\hline Fresh Fuel & $\begin{array}{l}\text { Ful1 reactor load in } \\
\text { storage prior to use }\end{array}$ & Uranium & 200 \\
\hline \multirow[t]{4}{*}{ Irradiated Fue] } & $\begin{array}{l}\text { In reactor during } \\
\text { equitibrium operation }\end{array}$ & $\begin{array}{l}\text { Uranium, Pu } \\
\text { Fission } \\
\text { Products }\end{array}$ & $1.8 \times 10^{10}$ \\
\hline & $\begin{array}{l}\text { In reactor--1 week } \\
\text { after shutdown }\end{array}$ & $\begin{array}{l}\text { Uranium, Pu } \\
\text { Fission } \\
\text { Products }\end{array}$ & $3.0 \times 10^{9}$ \\
\hline & $\begin{array}{l}\text { In storage--2 } \\
\text { months after shutdown }\end{array}$ & $\begin{array}{l}\text { Uranium, Pu } \\
\text { Fission } \\
\text { Products }\end{array}$ & $6.3 \times 10^{8}$ \\
\hline & $\begin{array}{l}\text { In storage-- } 6 \\
\text { months after shutdown }\end{array}$ & $\begin{array}{l}\text { Uranium, Pu } \\
\text { Fission } \\
\text { Products }\end{array}$ & $4.0 \times 10^{8}$ \\
\hline
\end{tabular}

(a) Basis: 1250 MWe pressurized water reactor with uranium fuel

a river and less than 10 person-rem/yr for a lake or ocean site. The population dose from a 2400 MWe BWR station is somewhat less at corresponding sites.

Principal pathways of exposure are fish, shoreline exposure and, at freshwatcr sites, drinking water. The nucl1des $c s-134$ and Cs-137 are the principal contributors to the total-body population doses from all these pathways, with lesser contributions from Co-58 and Co-60. With the most sophisticated radwaste systems, $\mathrm{H}-3$ made significant contributions in the drinking water pathway for PWR liquid effluents.

Radionuclides released with gaseous effluents from LWRs versus radwaste systems were also defined in WASH-1258. (1) Noble gas releases totaled $10^{3}$ to $5 \times 10^{4} \mathrm{Ci} / \mathrm{yr}$ for a PWR and $10^{3}$ to $3 \times 10^{6} \mathrm{Ci} / \mathrm{yr}$ for BWR. Relatively simple radwaste systems were capable of limiting releases to 
$210^{3} \mathrm{Ci} / \mathrm{yr}$ from a PWR and $i 104 \mathrm{Ci} / \mathrm{yr}$ from a BWR and reducing the air submersion dose rates at the 500-meter site boundary of a 2400 MWe, two-reactor station to less than the Appendix I guidel ine of $5 \mathrm{mrem} / \mathrm{yr}$. The population. doses associated with these reduced releases of noble gases ranged from 1 to 70 for a 2400 MWe BWR station and from 0.2 to 1 for the PWR station. These population doses are, of course, highly dependent upon population distribution around the site, especially as related to distance and the prevailing wind direction.

Releases of radioiodine 1 isted in WASH-1258 ranged from $10^{-2}$ to $15 \mathrm{Ci}$ I-131/yr/reactor for a BWR and from $10^{-2}$ to $1.2 \mathrm{ci} / \mathrm{yr} /$ reactor for a PWR. None of the potential radwaste systems could reduce the potential infant thyroid dose below the originally proposed guideline of $5 \mathrm{mrem} / \mathrm{yr}$ without the addition of a tall stack. Since these doses are calculated on the premise that a milk cow forages at the site boundary, the dose versus release relationship is highly dependent on distance to the site boundary. At a nuclear center the distance to the nearest possible cow pasture might be $10^{4}$ meters rather than the 500 meters assumed in the reference document.

Such an increase in distance could reduce air concentration of radioiodine and hence thyroid dose by a factor of 50 to 100 for ground level releases. This reduction might eliminate the need for a tall stack and still permit multireactor siting of 30,000 to 40,000 MWe at the NEC.

\section{E. FUEL REPROCESSING PLANTS}

When the irradiated fuel from the power reactors is dissolved in the reprocessing plants, the radionuclides in the fuel are released and enter either the reprocessing liquid streams or the gas atmospheres in the reprocessing equipment. These gaseous and liquid streams are then treated to remove the radionuclides for storage or reuse. The inventory of radioactive material at a reprocessing plant consists of fuel waiting to be processed and the wastes from fuel previously processed. Table 2 lists the inventory of radioactive material at a reprocessing plant versus the type of fuel being processed assuming the wastes are stored on site for 10 years prior to shipment to a Federal repository. 
TABLE 2. Inventory of Materials Stored at Fuel Reprocessing Plants

\begin{tabular}{|c|c|c|c|}
\hline Plant Type & LWR & HTGR & LMFBR \\
\hline roughput & 500 tonnes/yr & 260 tonnes/yr & 1500 tonnes $/ \mathrm{yr}$ \\
\hline ial Sto & $1.7 \times 10^{10} \mathrm{Ci}$ & $4.8 \times 10^{9} \mathrm{Ci}$ & $2.6 \times 10^{7}$ \\
\hline
\end{tabular}

Siting of reprocessing plants and associated waste management facilities was discussed in ORNL-4451. (2) At the time that document was prepared, the proposed Appendix I guideline and associated philosphy had not yet been prepared. As a result the authors assumed that control of routine releases of radionuclides could be based upon the air concentrations listed in 10 CFR 20. It may be assumed that a significant reduction below these latter air concentrations and resultant radiation doses, will be required by a future definition of "as low as practicable" for fuel reprocessing plants dictating more sophisticated radwaste treatment systems.

The Barnwell fuel reprocessing plant has a minimum site boundary distance of i2350 meters. The capacity of this plant is 1500 tonnes/yr of LWR fuels. Radionuclides will not normally be released with liquid effluents. Estimated release rates to the atmosphere taken from the Barnwell Environmental Report ${ }^{(13)}$ are 1 isted below.

\begin{tabular}{lll} 
Nuclide & & \multicolumn{1}{c}{$\mathrm{Ci} / \mathrm{yr}$} \\
\cline { 1 - 1 } $\mathrm{H}-3$ & & $5.8 \times 10^{5}$ \\
$\mathrm{Kr}-85$ & & $1.4 \times 10^{7}$ \\
$\mathrm{I}-129$ & & 0.047 \\
$\mathrm{I}-137$ & & 0.38 \\
Cs-134 & & 0.6 \\
Cs -137 & & 0.38
\end{tabular}


At the present time no removal systems for noble gases are commercially available and none appear to be needed at Barnwe11. The doses estimated from the releases listed above are summarized in Table 3. (13)

TABLE 3. Annual Radiation Doses Associated with Gaseou's Effluents from the Barnwell Plant

\begin{tabular}{|c|c|c|c|c|}
\hline $\begin{array}{l}\text { Exposure } \\
\text { Pathway }\end{array}$ & Organ & Nucl ide & $\begin{array}{c}\text { Individual } \\
\text { mrem }\end{array}$ & $\begin{array}{l}\text { Population } \\
\text { Person-rem }\end{array}$ \\
\hline Air Submersion & Total Body & $\mathrm{Kr}-85$ & 0.07 & 2 \\
\hline Air submersion & skin & KA- 85 & $\therefore 6.3$ & 180 \\
\hline $\begin{array}{l}\text { Inhalation and } \\
\text { Transpiration }\end{array}$ & Total Body & $\mathrm{H}-3$ & 0.4 . & 13 \\
\hline Milk-Infant & Thyroid & $I-131^{\circ}$ & 1.9 & 100 \\
\hline Milk-Infant & Thyroid & $I-129$ & 3.4 & 70 \\
\hline
\end{tabular}

The doses listed in Table 3 are well within the existing 10 CFR 20 guidelines and should be reasonably compatible with any forthcoming "as low as practicable" guidance for reprocessing plants. As stated before, siting such a plant at a nuclear center would automatically extend the site boundary to perhaps $10^{4}$ meters and reduce the radiation doses even further below the existing and proposed guides.

\section{F. WASTE MANAGEMENT FACILITIES}

Waste management facilities were discussed in ORNL-4451 and it was concluded that with proper design and siting any environmental radiological impact of such facilities would be minimal. Interim storage of high-level liquid wastes does not normally result in release of radioactive materials to the surfacc waters. Acceptably small releases of radionuclines to the atmosphere will occur routinely, and accidental leaks could release liquid 
material to the ground. For these reasons careful design and Judicious siting of a reprocessing plant and associated high-level liquid waste storage facilities must be accomplished. Siting of these facilities within a nuclear center where the distance to the nearest population is relatively large would normally result in lowered radiation doses to the offsite population.

Solidification of liquid wastes after a brief ( 3 to $5 \mathrm{yr}$ ) storage period should also be done at the site of the reprocessing plant for economic and safety reasons. It may be desirable to remove certain fission products and actinides from these wastes prior to solidification. The fission products $S r-90$ and $C s-137$ may be removed to reduce the heat generation rate within the solids and the actinides may be removed to reduce the extremely long time that the solid product remains highly radiotoxic.

Neither these removal processes nor the solidification itself should impose an unacceptable environmental impact provided that the proper design and siting as mentioned previously have been followed. The separated fission products would need to be encapsulated and placed in a cooled storage facility until such time that their heat rate has decreased significantly or alternately until some beneficial use could be found for them. The separated actinides could possibly be fabricated into suitable form for charging into an "actinide burner" for transmutation and fission. The radiological problems associated with this latter concept are discussed in more detail later. Properly encapsulated solidified wastes would be stored at an interim Retrievable Surface Storage Facility (RSSF) for several years prior to shipment to an ultimate disposal site.

Evaluation of the several concepts proposed for a Retrievable Surface Storage Facility is currently underway by the AEC and its contractors. (a) Such a facility would provide interim storage of solidified power reactor wastes until such time as they can be transferred to the ultimate disposal

(a) See, for example, References 14 and 15. 
wastes until such time as they can be transferred to the ultimate disposal site. Only minor radiological impact is predicted for the RSSF concepts evaluated to date.

\section{G. "ACTINIDE BURNER" NUCLEAR REACTOR}

It has been suggested that it may be desirable to remove long-live fission products and actinide elements from high-level wastes prior to solidification for separate disposal via transmutation. It is possible that this could be done without adding appreciably to the total fuel cycle costs. $(16,17)$ The technical feasibility of transmutation has been established; (16) however, several important problems remain to be addressed. For example; there may be some point in time when further recycling of actinide elements becomes unattractive because the elements are no longer suitable as reactor fuel and additional transmutation cannot be accomplished. At that point, the remaining actinides would again become part of the high-level wastes.

The processes of refabrication of the actinides into reactor fuel have not been established. Some persons believe the fabrication can only be done in heavily shielded facilities and that recycling these wastes could be best accomplished in an LMFBR because "there would be a smaller fuel manufacturing penalty, since the whole system is full of highly toxic gammaemitting plutonium already;..." (17) withnut. doubt there are many problems yet to be answered concerning any transmutation program. The facilities and expertise associated with a nuclear center could lend itself to finding solutions to these problems. It is conceivable that close cooperation between reprocessing and refabrication may be absolutely mandatory. Timing between separation and refabrication could be critical because of the in-growth of some radionuclides that might complicate refabrication.

H. OVERALL RADIOLOGICAL IMPACT ON MAN .

Primary radiological safety advantages of siting all of the fuel reprocessing, waste management and interim storage facilities at a nuclear power 
center include el imination of transportation over public highways of highly radioactive materials between the several process stages, and the increased distance between the facilities and the site boundary.

The disadvantages include the larger quantities of radionuclides discharged to air and water at one site compared to isolated facilities: There would not seem to be insurmountable problems with the combined releases to the atmosphere since the facilities would be well separated from each other and from the general public. The discharge of some several thousand $\mathrm{Ci} / \mathrm{yr}$ of tritium and $210 \mathrm{Ci} / \mathrm{yr}$ each of $\mathrm{Cs}-134, \mathrm{Cs}-136$ and $\mathrm{Cs}-137$ to one body of water from the two dozen or so reactors may indeed present environmental impact problems. Special radwaste systems and/or operating procedures may be required to permit siting of 30,000 to 40,000 MWe of nuclear power at one location, unless the aquatic environment has an unusual capacity for safely receiving large quantities of radionuclides.

The radiological impact of releases of radioiodine and noble gases to the atmosphere from 25 power reactors and a fuel reprocessing plant is difficult to estimate without detailed calculations of the contribution from each source to the total dose. The population dose could be approximated by assuming all of the releases occurred at some one point, an effective average distance from the boundary (not necessarily the geographical center of the center). On this basis, it was estimated that the total population dose from all sources combined could be restricted to no more than 100 to 200 person-rem/yr.

The maximum individual dose would probably be to an infant consuming inflk from a cow pastured at the closest possible point to a facility (probably the reactor nearest the site boundary). This dose would be dependent upon the releases from the nearest facility, with additional contributions from the combined releases of the other facilities probably increasing the total dose by a factor of 2 to 5 .

As the distance to the nearest facility increased, the total dose would decrease and the relative contribution of that one facility to the dose would also decrease. It appears that the maximum individual doses 
calculated for the Proposed Appendix I Environmental Statement ${ }^{(1)}$ could be used with appropriate corrections for multiple sources and increased site boundary distances to estimate the doses at the nuclear energy center. The net result is that the infant thyroid doses would probabiy be about twice those listed in Reference 1 for each specific rad-waste case. This implies that tall stacks might still be required, at least at the facilities closest to the site boundary, to meet the proposed guidelines.

\section{REFERENCES}

1. Directorate of Regulatory Standards, Final Environmental Statement Concerning Proposed Rule Making Action: Numerical Guides for Design objectives and Limiting Conditions for Operation to Meet the Criterion "As Low as Practicable" for Radioactive Material in Light-Water-Cooled Nuclear Power Reactor Effluents, WASH-1258, U. S. Atomic Energy Commission, Washington, D.C., JuTy 1973.

2. Oak Ridge National Laboratory, Siting of Fuel Reprocessing Plants and Waste Management Facilities, USAEC Report ORNL-445T, Oak Ridge, TN, 1970.

3. W. D. Turner, S. V. Kaye, P. S. Rohwer, EXREM and INREM Computer Codes for Estimating Radiation Doses to Populations from Construction of a Sea Level Canal with Nuclear Explosives, K=1752, Computing Techiro ogy Center and Oak Ridge National Lab, Oak Ridge TN, 1968.

4. D. L. Strenge, M. M. Hendrickson and E. C. Watson, RACER-A Computer Program for Calculating Potential External Dose from Airborne.Fission Products Following Póstulated Reactor Accidents, USAEC Rejurt BNWL-B-69, Battelfe-Northwest, Richland, WA, 1971 .

5. D. K. Tubey, S. V. Kaye, The EXREM III Computer Code for Estimating External Radiation Doses to Populations from Environmental Releases, ORNL-TM-4322, Oak Ridge Nationa 1 Laboratory, Oak Ridge, TN, 1973.

6. D. L. Strenge, E. C. Watson, KRONIC - A Computer Program for Calculating Annual Average External Doses from Chronic Atmospheric Releases of Radionuclides, USAEC Report BNWL-B-264, Battelle-Northwest, Richland, WA, June 1973 . 


\section{REFERENCES (Continued)}

7. J. K. Soldat, "Radiation Dose Model," in HERMES - A Digital Computer Code for Estimating Regional Radiological Effects from the Nuclear Power Industry, (J. F. Fletcher and W. L. Dotson, compilers), USAEC Report HEDL-TME-71-168, Hanford Engineering Development Laboratory, Richland, WA, pp. 81-161, 1971.

8. J. K. Soldat, Modeling of Environmental Pathways and Radiation Doses from Nuclear Facilities, USAEC Report BNWL-SA-3939, Battelle-Northwest, Richland, WA, 1971.

9. J. K. Soldat, N. M. Robinson and D. A. Baker, Models and Computer Codes For Evaluating Environmental Radiation Doses, USAEC Report BNWL-1754, Battelle-Northwest, Richland, WA, June 1973.

10. J. K. Soldat, D. A. Baker, J. P. Corley, Applications of a General Computational Model for Composite Environmental Radiation Doses, IAEA Symposium on Environmental Behavior of Radionuclides Released in the Nuclear Industry, Aix-en-Provence, France, May 14-18, 1973 (IAEA/SM-172/82, to be published in the Symposium Proceedings; also BNWL-SA-4511, Battel le-Northwest, Richland, WA, April 1973).

11. J. M. Selby, et al., Considerations in the Assessment of the Consesequences of Effluents from Mixed 0xide Fuel Fabrication PTants, USAEC Report BNWL-7697, Battelle-Northwest, Richland, WA, 1973.

12. L. G. Faust, private communication to J. K. Soldat, January 4, 1974.

13. Barnwell Nuclear Fuel Plant, Environmental Report, Docket No. 50-332, Al7ied-Gulf Nuclear Services, Barnwe11, SC, November 1971.

14. Atlantic Richfield Hanford Co. and Kaiser Engineers, Retrievable Surface Storage Facility Water Bas in Concept, System Design Description, USAEC Report ARH-2799, Atlantic Richfield Hanford Co., Richland, WA, 1973.

15. J. R. LaRiviere (compiler), Retrievable Surface Storage Facility Sealed Storage Cask Concept - Feasibility Study, USAEC Report ARH-2801, Atlantic Richfield Hanford Co., Richland, WA, 1973.

16. W. C. Wolkenhauer, Transmutation Processing/El imination, Preliminary Draft Report, Battelle-Northwest, Richland, WA, 1973.

17. A. S. Kubo and D. J. Rose, "Disposal of Nuclear Wastes, Science, Vol. $182,1205,1973$. 